\title{
寒冷地において使用される高炉スラグ微粉末 混和コンクリートの強度発現性に関する研究
}

\author{
岩城一郎 ${ }^{* 1} \cdot$ 澤井洋介 ${ }^{2} \cdot$ 梶谷浩和 ${ }^{* 3} \cdot$ 三浦尚 ${ }^{* 4}$
}

\begin{abstract}
概 要 高炬スラグ微粉末を混和した高流動コンクリートと普通コンクリートを対象にモルタル供試 体を作製し, 寒冷地を想定した様々な温度条件下における強度発現性を調べた。その結果, 高炉スラグ微 粉末の混和の有無, 高炬スラグ微粉末の粉末度と置換率の組合せ, 高流動コンクリートと普通コンクリー トの違いにより強度発現性が異なる傾向を示すことを確認した。そこで, 高炉スラグ微粉末混和コンクリ 一トの圧縮強度に及ぼす高炉スラグ微粉末の影響を定量評価するための手法を考案し,この種のコンクリ 一トの強度発現性に及ぼす配合条件, 温度条件の影響を検討した。
\end{abstract}

キーワード: 高炉スラグ微粉末, 強度発現, 養生, 高流動コンクリート, 強度寄与率

\section{1. はじめに}

近年, 地球環境問題に配虑し，セメントの製造に伴う 二酸化炭素排出量の削減を図るため, セメントの代替と なる廃棄物の有効利用が検討されている。また, 高性能 （AE）減水剤の開発や各種混和材の利用により, コンク リートの強度, 流動性, 耐久性といった性能を飛躍的に 向上させた高性能コンクリートの開発が進められている。 今後, こうしたセメント・コンクリート産業の省資源・ 省エネルギー化, 及びコンクリートの高性能化に伴い, 産業副産物である高炉スラグ微粉末を混和したコンクリ 一トの需要が增加するものと予想される。高炉スラグ微 粉末を混和したコンクリートは, これを混和しない同一 水結合材比のコンクリートと比較し, 強度発現が遅延し, その傾向は低温下で一層顕著に現れるため ${ }^{1)}$, これまで どちらかというと寒冷地においては，その使用に消極的 であったと言える。しかしながら，高炬スラグ微粉末を 混和したコンクリートはアルカリシリカ反応の抑制, 耐 硫酸塩性や海水に対する化学抵抗性の向上といった効果 1)が期待できるため, 融雪剤として塩化物が散布される 環境下や海洋環境下では, コンクリートの耐久性を向上 させる上で，非常に有効なコンクリートであると言える 2)。加えて, 高炬スラグ微粉末は, 高流動コンクリート
や高強度コンクリートの粉体, 結合材としても汎用性の 高い材料であることから, 今後, 寒冷地においてもこの 種のコンクリートを普及させる上で, 高炉スラグ微粉末 のより積極的な使用が望まれる。

寒冷地において高炉スラグ微粉末を混和したコンクリ 一トを使用する場合, 前述のように, 一般のコンクリー 卜と比較して強度発現が遅延するため, 要求される強度 発現性を満足するよう, 配合, 養生方法を慎重に選定す る必要がある。そのためには, 寒冷地を想定した様々な 温度条件に対する高炬スラグ微粉末混和コンクリートの 強度発現性を十分に把握しておくことが重要である。そ こで本研究では, はじめに高炬スラグ微粉末を混和した 粉体系高流動コンクリートと普通コンクリートを対象に, (1)常温と低温でそれぞれ一定養生を行った場合, (2)冬か ら春への季節の変化を想定し, 材齢途中で低温から常温 へ温度上昇させた場合, (3)打込み後所定の期間給熱養生 を行い，その後低温養生を継続した場合について，その 強度発現性を調查することとした。実験の結果, 高炬ス ラグ微粉末の混和の有無, 高炬スラグ微粉末の粉末度と 置換率の組合せ, 高流動コンクリートと普通コンクリー トの違いにより, 各温度条件に対する強度発現性が異な る傾向を示すことが確認された。このように, 配合条件, 温度条件によって高炉スラグ微粉末混和コンクリートの

\footnotetext{
*1 東北大学大学院講師 工学研究科土木工学専攻 博士（工学）(正会員） T980-8579 宮城県仙台市青葉区荒巻字青葉 06

*2 東北大学大学院院生 工学研究科土木工学専攻 $\overline{7} 980-8579$ 宮城県仙台市青葉区荒巻字青葉 06

*3 使ピー・エス （元 東北大学学生 工学部土木工学科） †100-0005 東京都千代田区丸の内 3-4-1

*4 東北大学大学院教授 工学研究科土木工学専攻 工博（正会員） T980-8579 宮城県仙台市青葉区荒巻字青葉 06
} 
表-1 セメントの試験成績

\begin{tabular}{|c|c|c|c|c|c|c|c|c|c|c|c|c|c|}
\hline \multirow{2}{*}{$\begin{array}{c}\text { 密度 } \\
\left(\mathrm{g} / \mathrm{cm}^{3}\right) \\
\end{array}$} & \multirow{2}{*}{$\begin{array}{l}\text { 比表面積 } \\
\left(\mathrm{cm}^{2} / \mathrm{g}\right)\end{array}$} & \multicolumn{3}{|c|}{ 凝結 } & \multirow{2}{*}{ 安定性 } & \multicolumn{3}{|c|}{ 圧縮強さ $\left(\mathrm{N} / \mathrm{mm}^{2}\right)$} & \multirow{2}{*}{\begin{tabular}{|c|}
$\mathrm{MgO}$ \\
$(\%)$
\end{tabular}} & \multirow{2}{*}{\begin{tabular}{|c|}
$\mathrm{SO}_{3}$ \\
$(\%)$ \\
\end{tabular}} & \multirow{2}{*}{\begin{tabular}{|c|} 
L.O.I \\
$(\%)$
\end{tabular}} & \multirow{2}{*}{\begin{tabular}{|c} 
全アルカリ \\
$(\%)$ \\
\end{tabular}} & \multirow{2}{*}{$\begin{array}{l}\mathrm{Cl}^{-} \\
(\%) \\
\end{array}$} \\
\hline & & 水量 (\%) & 始発 (h-m) & 終結 (h-m) & & 3 日 & 7日 & 28日 & & & & & \\
\hline 3.16 & 3290 & 28.1 & $2-26$ & 3-39 & 良 & 26.5 & 42.4 & 60.1 & 1.5 & 2.0 & 1.3 & 0.61 & 0.005 \\
\hline
\end{tabular}

表-2 高炉スラグ微粉末の試験成績

\begin{tabular}{|c|c|c|c|c|c|c|c|c|c|c|c|}
\hline 密度 & 比表面積 & L.O.I & $\mathrm{SiO}_{2}$ & $\mathrm{Al}_{2} \mathrm{O}_{3}$ & $\mathrm{Fe}_{2} \mathrm{O}_{3}$ & $\mathrm{CaO}$ & $\mathrm{MgO}$ & $\mathrm{SO}_{3}$ & \multicolumn{3}{|c|}{ 活性度指数 } \\
\hline$\left(\mathrm{g} / \mathrm{cm}^{3}\right)$ & $\left(\mathrm{cm}^{2} / \mathrm{g}\right)$ & $(\%)$ & $(\%)$ & $(\%)$ & $(\%)$ & $(\%)$ & (\%) & $(\%)$ & 材齢7日 & 材齢28日 & 材齢91日 \\
\hline 2.92 & 4450 & 0.0 & 33.2 & 14.8 & 0.4 & 42.6 & 6.0 & 0.1 & 61 & 99 & 113 \\
\hline 2.91 & 7980 & 0.0 & 33.4 & 14.5 & 0.79 & 42.8 & 5.58 & 0.1 & 113 & 129 & 114 \\
\hline
\end{tabular}

表-3 基本となる配合

\begin{tabular}{|c|c|c|c|c|c|c|c|c|c|c|}
\hline \multirow{2}{*}{$\begin{array}{c}\text { 粗骨材の } \\
\text { 最大寸法 } \\
(\mathrm{mm})\end{array}$} & \multirow{2}{*}{$\begin{array}{l}\text { 自己 } \\
\text { 充てん性 } \\
\text { のランク }\end{array}$} & \multirow{2}{*}{$\begin{array}{l}\text { 目標スランプ } \\
\text { フロー } \\
(\mathrm{mm})\end{array}$} & \multirow{2}{*}{$\begin{array}{l}\mathrm{V} \text { 漏斗 } \\
\text { 流下時間 } \\
\text { (秒) }\end{array}$} & \multirow{2}{*}{$\begin{array}{c}\text { 水結合 } \\
\text { 材比 } \\
(\%)\end{array}$} & \multirow{2}{*}{$\begin{array}{c}\text { 水粉体 } \\
\text { 容積比 } \\
(\%)\end{array}$} & \multicolumn{5}{|c|}{ 単位量 $\left(\mathrm{kg} / \mathrm{m}^{3}\right)$} \\
\hline & & & & & & $\begin{array}{l}\text { 水 } \\
W\end{array}$ & $\begin{array}{c}\text { セメント } \\
\mathrm{C}\end{array}$ & $\begin{array}{c}\text { スラグ } \\
\text { BS }\end{array}$ & $\begin{array}{c}\text { 細骨材 } \\
\text { S }\end{array}$ & $\begin{array}{c}\text { 粗骨材 } \\
\text { G }\end{array}$ \\
\hline \multirow{3}{*}{20} & \multirow{3}{*}{2} & \multirow{3}{*}{$650 \pm 50$} & \multirow{3}{*}{$7 \sim 13$} & \multirow{3}{*}{35} & 1110.3 & 175 & 500 & 0 & 824 & 849 \\
\hline & & & & & 105.7 & 175 & 250 & 250 & 816 & 841 \\
\hline & & & & & 104.0 & 175 & 150 & 350 & 811 & 835 \\
\hline
\end{tabular}

強度発現性が大きく異なる理由は, 高炉スラグ微粉末の 反応性に起因すると考えられるため, 高炉スラグ微粉末 混和コンクリートの圧縮強度に及ぼす高炬スラグ微粉末 の影響を定量評価するための手法を考案し，この種のコ ンクリートの強度発現性に及ぼす配合条件, 温度条件の 影響を検討した。

\section{2. 実験概要}

本研究は, 2 種類の実験シリーズに大別される。実験 シリーズ I は, 配合条件, 温度条件の違いによる高炉ス ラグ微粉末混和コンクリートの強度発現性を調べるため のものであり, 実験シリーズ II は, 高炉スラグ微粉末混 和コンクリートの圧縮強度に及ぼす高炬スラグ微粉末の 影響を評価するための手法を考案し，実験シリーズ I の 結果を考察するためのものである。尚, 本研究では, 実 験シリーズ I, II ともにモルタル供試体により実験を行 っている。その理由は, 温度条件がコンクリートの強度 発現性に及ぼす影響を調べるのであれば，良質な粗骨材 を使用し，材料分離の少ないコンクリートである限り， 粗骨材の有無が強度発現性に及ぼす影響は小さいと判断 されるためである。また, 粗骨材が mixing 効果に及ぼす 影響も無視することはできないと考えられるが，本研究 で対象としているコンクリートの単位粗骨材量は配合間 で大きな違いが見られず，かつ適正な量であるため（表 -3 参照), 本研究の範囲内ではこの影響も十分に小さい と判断した。以下に各実験シリーズの概要について記す。

\section{1 実験シリーズ।}

寒冷地を想定した温度条件に対する高炬スラグ微粉末 混和コンクリートの強度発現性については, 著者らによ ってこれまでにも調べられてきた ${ }^{3), 4), 5), 6) 。 し か し な か ゙ ~}$
ら,これらの研究は高流動コンクリート, 普通コンクリ 一トに対して各々個別に調べられてきたものであり，使 用材料, 配合条件, 温度条件については統一性を持たな かった。加えて, 実験シリーズ I のデータは, 実験シリ 一ズ II で検討を行うための基本データとなるため, 本研 究では高流動コンクリートと普通コンクリートで, 使用 材料, 配合条件, 温度条件を統一し, 新たに実験を行な うこととした。尚，実験シリーズ I で得られたデータの 一部は，既往の文献》においても使用されている。

（1）使用材料及び配合

セメントは普通ポルトランドセメント，高炬スラグ微 粉末は JIS 規格品である高炉スラグ微粉末 4000 と高炉ス ラグ微粉末 8000 の 2 種類を使用した。表-1, 表-2 にセ メント及び高炬スラグ微粉末の試験成績結果をそれぞれ 示す。細骨材は山砂（宮城県大和町産, 密度 $2.60 \mathrm{~g} / \mathrm{cm}^{3}$, 粗粒率 2.82, 吸水率 $2.05 \%$ ）を使用した。高性能 $\mathrm{AE}$ 減 水剂はポリカルボン酸エーテル系のものを使用した。

高流動コンクリートを対象としたモルタルの配合設計 は, 高流動コンクリート施工指針)中の配合設計マニュア ルに示されているモルタル配合の設定手順及び標準値を 遵守し, 高性能AE減水剂添加量については, 既往の文献 9に従いモルタルフロー試験を行って, 所定の高流動性が 得られるように調整した。その結果，表-3に示す水結合 材比35\%, スラグ置換率0\%，50\%，70\%の3種類の配合か ら粗骨材を取り除くことによりモルタル配合を設定した。 スラグ置換率を50\%及び70\%に設定した理由は，既往の 文献1より, 高流動性を付与し, かつアルカリシリカ反応 の抑制, 耐硫酸塩性及び塩分に対する化学抵抗性の向上 を目的としたコンクリートを施工する場合，この程度の 置換率が下限及び上限になると判断されるためである。 一方, 普通コンクリートを対象としたモルタルの配合は, 

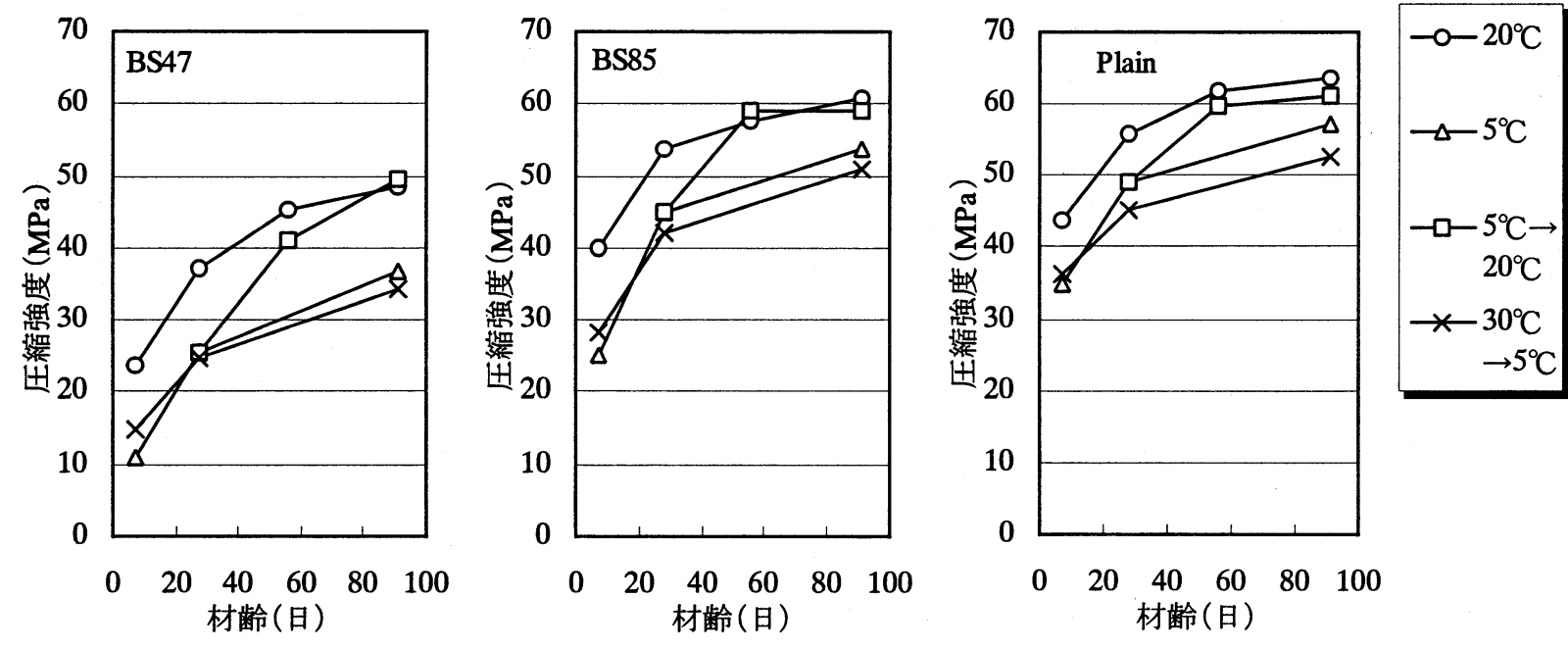

図-1 各温度条件に対する強度発現性

（高流動コンクリート W/B=35\%)

水結合材比 $50 \%$, 水: 結合材 : 細骨材の比を, $0.5: 1$ : 2.5に設定し，スラグ置換率を0\%，50\%，70\%の3水準で 変化させた。一般に, 高炉スラグ微粉末を混和したコン クリートは, 粉末度が低く置換率が高いほど強度発現が 遅延することが知られているため, 本研究においては, 強度発現の遅延が懸念される配合として高炉スラグ微粉 末4000を置換率70\%で混和した配合(以下BS47と記す)， 比較的良好な強度発現性を示す配合として高炬スラグ微 粉末 8000 を置換率50\%で混和した配合 (以下BS85 と記す) を選定し, 各温度条件に対する強度発現性を調べること とした。さらに，高炬スラグ微粉末を混和しないプレー ンな配合（置換率0\%，以下Plainट記す）に対しても同様 の実験を行い, 高炬スラグ微粉末の混和の有無が強度発 現性に及ぼす影響を比較検討した。

\section{（2）実験方法}

モルタルは $20^{\circ} \mathrm{C}$ 恒温室内で練り混ぜ, $\phi 5 \times 10 \mathrm{~cm}$ の円 柱型枠に打込み後, 標準的な養生温度である $20^{\circ} \mathrm{C}$ と, 寒 冷地における日平均気温を想定した温度である $5^{\circ} \mathrm{C}$ に設 定した恒温室内でそれぞれ養生した。また，冬から春へ の季節の変化に伴う温度上昇がコンクリートの強度回復 に及ぼす影響を調べる実験では, $5^{\circ} \mathrm{C}$ 恒温室で養生を行っ た供試体を材齢 28 日で $20^{\circ} \mathrm{C}$ 恒温室に移設し, 以降 $20^{\circ} \mathrm{C}$ 養生を継続した。一方，給熱養生が強度発現性に及ぼす 効果を調べる実験では, 打込み後 $30^{\circ} \mathrm{C} て ゙ 1$ 日間養生を行 った供試体を $5^{\circ} \mathrm{C}$ 恒温室に移設し, 以降 $5^{\circ} \mathrm{C}$ 養生を継続し た。養生方法は, 寒冷地における現場の状況を想定し, 望ましいと判断される封かん養生を採用した。その理由 は，寒冷地でコンクリートを施工する場合，気中養生で は十分な強度が得られないことがわかっており ${ }^{5)}$ ，また 寒冷地における実際の現場で長期にわたり水中養生を継 続することは難しいと考えられるためである。供試体は 脱型直後に食品用ラップフィルム及びチャック付きポリ エチレン袋で二重に密封し，水分の出入りを遮断した。
圧縮強度試験は, JIS A 1108 に従い, 材龄 7 日，28日， 91 日（一部 56 日）で行うこととした。

\section{2 実験シリーズ॥}

実験シリーズ II で使用した材料は実験シリーズ I と同 じである。実験シリーズ II では, コンクリートの圧縮強 度とセメント水比との間に直線関係が成り立つことを利 用し，高炉スラグ微粉末混和コンクリートの圧縮強度に 及ぼす高炬スラグ微粉末の影響を評価する手法を考案し た。压縮強度とセメント水比との関係式を求めるため, 水セメント比を $35 \%, 50 \% ， 70 \% ， 100 \% ， 117 \% ， 167 \%$ と変化させた高炉スラグ微粉末を混和しないモルタル供 試体を作製し，各温度条件下で材齢 7 日，28 日，91 日 (一 部 56 日）の圧縮強度を測定した。これらの配合は, 実験 シリーズ I で示した高炬スラグ微粉末を混和したモルタ ル配合中の高炬スラグ微粉末をセメント及び細骨材と置 換することにより設定した。高性能 $\mathrm{AE}$ 減水剤について は, 低空気量タイプのものを使用し，各配合ごとに打込 みに必要な流動性が得られるよう添加量を調整した。JIS A 1116 に規定されている重量方法に従いモルタル中の 空気量を測定した結果，その範囲は $6.1 \%$ から $7.8 \%$ と配 合間で大きな違いは見られなかった。また, ブリーディ ングは各配合で多少変化したが，その影響を考虑し，実 水セメント比により後述の検討（3.2 参照）を行なった 結果，配合上の水セメント比により検討を行った結果と 比較し，大きな違いは認められなかった。そこで，本研 究では, 配合上の水セメント比に基づいて検討を進める こととした。

\section{3. 実験結果及び考察}

\section{1 実験シリーズ।}

はじめに，高炬スラグ微粉末を混和した高流動コンク リートと普通コンクリートを対象としたモルタル供試体 の各温度条件に対する実験結果を総括する。図-1に高流 

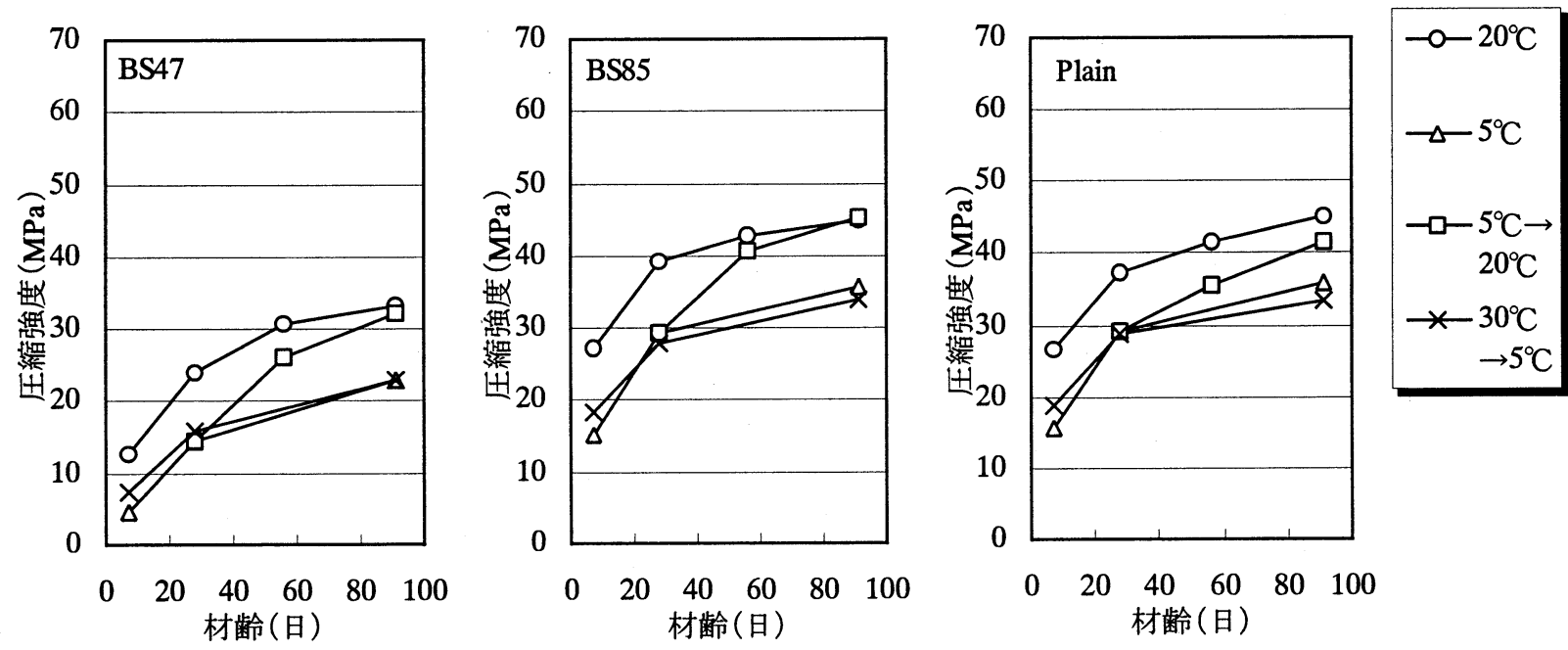

図-2 各温度条件に対する強度発現性 （普通コンクリート $\mathrm{W} / \mathrm{B}=50 \%$ ）

動コンクリートを対象としたモルタル供試体の各温度条 件に対する強度発現結果を示す。各配合の $20^{\circ} \mathrm{C}$ 養生と $5^{\circ} \mathrm{C}$ 盖生の強度発現結果に着目すると, BS 47 では $20^{\circ} \mathrm{C}$ 養 生と比べ, $5^{\circ} \mathrm{C}$ 養生の初期の強度発現が著しく遅延し, 材 齢 7 日で $10.9 \mathrm{MPa}$ の強度しか得られない。コンクリート 標準示方書 [施工編] 10)を参照し, 激しい気象作用を受 けるコンクリートの養生終了時に必要な圧縮強度 （15MPa）を本研究における材齢 7 日の目標強度とする と, BS47では $5^{\circ} \mathrm{C}$ 養生を行った場合, 目標強度を下回る ことになり, 初期凍害やその後春までに受ける凍結融解 作用に対して十分な抵抗性を示さない恐れがある。また, $5^{\circ} \mathrm{C}$ 養生を行った場合, 材龄が経過しても $20^{\circ} \mathrm{C}$ 養生の強 度発現と大きな開きがあることから，低温下においては 長期の強度発現性にも問題が生じる可能性がある。BS85 では, $20^{\circ} \mathrm{C}$ 盖生と比較し, $5^{\circ} \mathrm{C}$ 養生の初期の強度発現が多 少遅延するものの, 材跉 7 日強度は $25.0 \mathrm{MPa}$ と十分に高 く, その後 $20^{\circ} \mathrm{C}$ 養生の強度発現に近づく傾向を示してい る。一方, Plain では, BS47, BS85 と比較し, $5^{\circ} \mathrm{C}$ 養生 の初期の強度発現が良好で, 長期の強度発現も問題が少 ないと判断される。次に, 材齢途中の温度上昇が強度発 現の回復に及ぼす影響に着目する。BS47, BS85 では, $5^{\circ} \mathrm{C}$ 養生を行った場合, 初期の強度発現が遅延するものの, 材龄 28 日での温度上昇に伴い, 顕著に強度回復し, BS85 では材齢 56 日，BS47 では材齢 91 日で，それぞれ $20^{\circ} \mathrm{C}$ 養生の圧縮強度を上回っている。BS85 の材齢 91 日強度 は， $20^{\circ} \mathrm{C}$ 養生の圧縮強度を再び下回るが，この結果には ばらつきが含まれていると判断される。一方, Plain では, 温度上昇に伴い強度発現が多少回復するものの, $20^{\circ} \mathrm{C}$ 養 生の強度発現に追いつくことはない。従って, 高炬スラ グ微粉末を混和した高流動コンクリートは, 低温環境下 において初期の強度発現が遅延するものの, 封かん状態 が保たれていれば冬から春への季節の変化に伴い, 顕著 に強度回復することが示された。さらに, 打込み後給熱
養生を行った場合の強度発現性について, $5^{\circ} \mathrm{C}$ 養生を継続 した場合の強度発現性と比較すると, BS47に対して給熱 盖生を行なった場合, 材齢 7 日強度は $14.7 \mathrm{MPa}$ と改善し, 目標強度（15MPa）をほほ満足している。しかしながら, 材齢長期の強度発現は $5^{\circ} \mathrm{C}$ 養生と比較し, むしろ低下し ている。一方, BS85, Plain では, $5^{\circ} \mathrm{C}$ 養生を行なった場 合においても材齢 7 日の目標強度（15MPa）を十分満足 し，その後も比較的良好な強度発現性が得られるのに対 し, 給熱盖生を行なうと, むしろ $5^{\circ} \mathrm{C}$ 養生と比較し, 長 期の強度発現性に悪影響を及ぼすため, 経済性も考慮す るとこれらの配合に対してはむしろ給熱養生を施すべき ではないと判断される。

図-2 に普通コンクリートを対象としたモルタル供試 体の各温度条件に対する強度発現結果を示す。普通コン クリートは, 高流動コンクリートに比べ, 水結合材比が 高く, その結果強度は明らかに低いものの, 各温度条件 に対する配合間（BS47, BS85, Plain）での強度発現性 の違いは，ほぼ同様である。すなわち，(1)BS47では，低 温下で材齢初期の圧縮強度が著しく低い值を示すものの, その後の温度上昇に伴い, 強度発現が顕著に改善し, ま た給熱養生により初期強度が改善されること, (2)BS85 では, BS47に比べ, 強度発現上の問題が少なく, 温度上 昇に伴い顕著な強度回復を示すものの, 給熱養生による 初期の強度発現改善効果は少なく, むしろ長期の強度発 現性に悪影響を及ぼすこと, (3)Plain では低温下において も比較的良好な強度発現性を示すものの, 温度上昇に伴 う強度回復は顕著に現れず, 給熱養生による効果も BS85 と同様，あまり期待できないことなどである。

次に, 各温度条件に対する高流動コンクリートと普通 コンクリートの強度発現性を比較する。図-3 は, 低温養 生を行った場合の高流動コンクリートと普通コンクリー 卜の強度発現性を比較した結果である。図中の強度発現 率-1 とは各材齢の $5^{\circ} \mathrm{C}$ 養生を行った場合の圧縮強度を 
$20^{\circ} \mathrm{C}$ 養生の圧縮強度で除して百分率で表した值である。 すなわち, この值が高いほど, 常温を基準とした場合の 低温下での強度発現性に優れていることになる。図より, どの配合（BS47, BS85, Plain）においても, 高流動コ ンクリートは普通コンクリートに比ベ, 強度発現率が高 い值を示しており, 高流動コンクリートの方が, 普通コ ンクリートに比ベ, 低温下での強度発現性に優れている と判断される。このような結果が得られた理由として, 高流動コンクリートは普通コンクリートと比較し水結合 材比が低く, 結合材粒子間距離が短いため, 水和の進行 が遅い低温下においても, 細孔組織が繳密化し, 強度の 増加につながったことが一因として挙げられる。また, 高流動コンクリートでは高性能 $\mathrm{AE}$ 減水郕を多量に添加 しているため, 結合材粒子が分散し, 低温下においても 比較的円滑に水和が進行したことも影響していると考え られる。図-4は, 温度上昇を行った場合の高流動コンク リートと普通コンクリートの強度発現性を比較した結果 である。図中の強度発現率-2 は各材齢の温度上昇を行っ た場合の圧縮強度を $20^{\circ} \mathrm{C}$ 養生の圧縮強度で除して百分 率で表した值である。すなわち, この值が高いほど, 温 度上昇に伴う強度回復が顕著に現れていることになる。 図より, BS85 の材齢 91 日を除いて, 強度発現率は高流 動コンクリートが普通コンクリートを上回っており, 温 度上昇を行った場合の強度回復は概して高流動コンクリ 一トの方が普通コンクリートよりも良好であると判断さ れる。高炉スラグ微粉末を混和した高流動コンクリート に対して, 材齢途中で温度上昇させた場合, 顕著な強度 回復を示した理由は, 高炉スラグ微粉末の反応性が温度 に依存しやすいこと, すなわち低温では反応性が低下す るものの, 温度上昇に伴い反応が活性化する性質と, 水 結合材比の低い配合では, 常温養生を行うと比較的早期 に反応に必要な水分が不足し, 水和度が $100 \%$ に達しな いうちに強度発現の頭打ちを引き起こすことによる相互 作用であると考えられる。これに対して, 普通コンクリ 一トでは, 高流動コンクリートと比較し, 水結合材比が 高く, 材齢が経過しても水和に必要な水分が十分に残存 していることから $20^{\circ} \mathrm{C}$ 養生においても長期にわたり水 和が進行すると考えられ, その結果として強度発現率が 低い值を示したと推察される。以上の点については, 今 後, 各配合に対する材踰の経過に伴う細孔量, 水酸化力 ルシウム量, 残存する自由水量等の変化に着目し, 考察 の裏づけとなるデータの蓄積を進める必要がある。図-5 は, 給熱養生を行った場合の高流動コンクリートと普通 コンクリートの強度発現性を比較した結果である。図中 の強度発現率-3 とは各材跉の給熱養生を行った場合の圧 縮強度を $5^{\circ} \mathrm{C}$ 養生の圧縮強度で除して百分率で表した值 である。すなわち, この值が高いほど, 給熱養生の効果 があったと判断される。図より, 給熱養生による強度改 善効果は, 普通コンクリートの方が高流動コンクリート

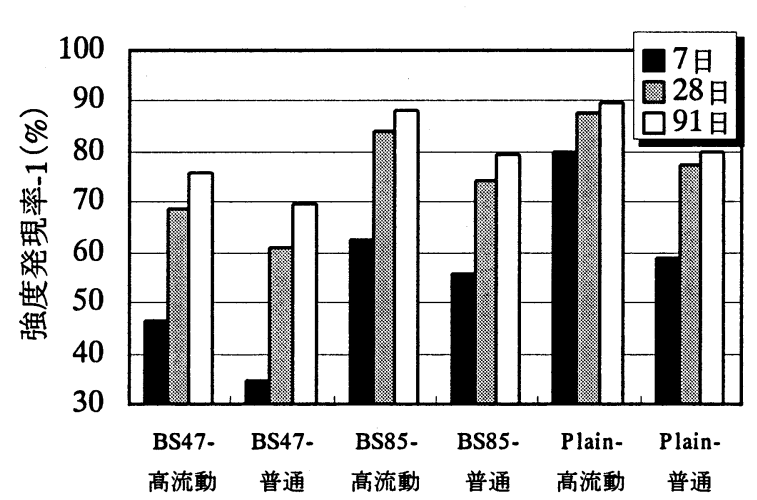

图-3 高流動コンクリートと普通コンクリートの比較 $\left(20^{\circ} \mathrm{C}\right.$ 飬 生に対する $5^{\circ} \mathrm{C}$ 養生の強度発現率)

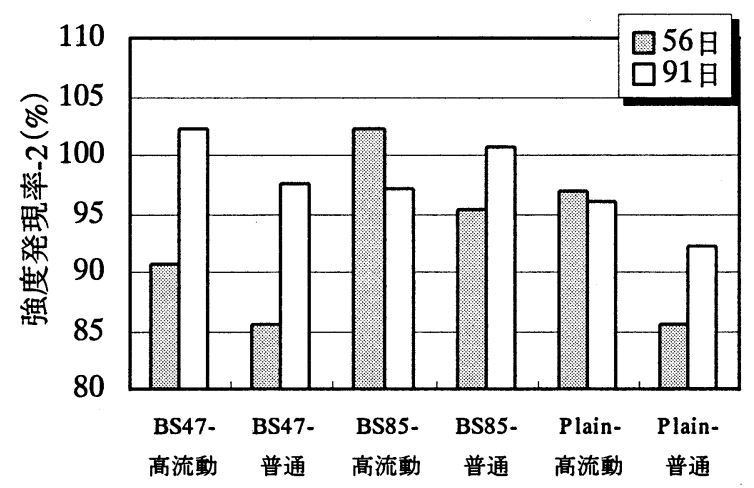

図-4 高流動コンクリートと普通コンクリートの比較 $\left(20^{\circ} \mathrm{C}\right.$ 篒 生に対する温度上昇を行った場合の強度発現率)

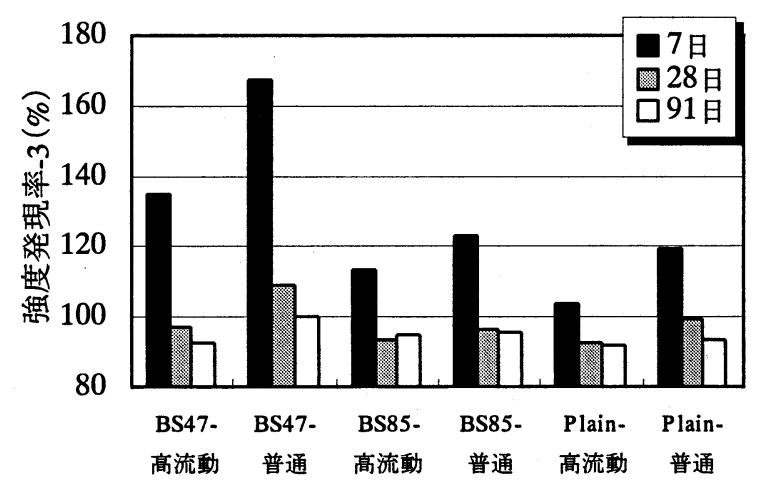

図-5 高流動コンクリートと普通コンクリートの比較 $\left(5^{\circ} \mathrm{C}\right.$ 褰 生に対する給熱養生を行った場合の強度発現率)

に比べ良好であり, その傾向は材齢初期でより顕著に現 れている。また, 高流動コンクリート, 普通コンクリー トともに強度発現性に優れた BS85, Plain に比べ, 強度 発現性の低い BS47 で, 給熱養生による効果がはっきり と現れている。このような結果が得られた理由は, 給熱 養生による初期の水和反応の促進効果とその後の細孔組 織の粗雑化が, 水結合材比や高炬スラグ微粉末の粉末度, 置換率といった要因によって, 相互に関連し, 異なる傾 向を示すためであると考えられる。この点については, 今後さらに詳細な検討を行う必要がある。

\section{2 実験シリーズ ॥}

実験シリーズ I で示した, 様々な温度条件に対する各 
配合の強度発現性の違いは, 高炬スラグ微粉末の反応性 に起因していると考えられる。一般に, 高炬スラグ微粉 末は普通ポルトランドセメントと比較し, 初期の反応が 遅延し，その傾向は低温下でより顕著に現れることが知 られているが, 高炉スラグ微粉末の反応性をセメント化 学の見地から定量的に評価した研究例 111は, 数が少なく, 測定方法も難しいという問題がある。一方, 高炬スラグ 微粉末（あるいはフライアッシュ）混和コンクリートの 圧縮強度の測定結果より, 高炉スラグ微粉末固有の活性

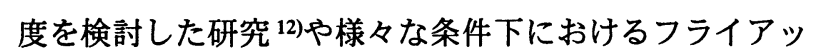

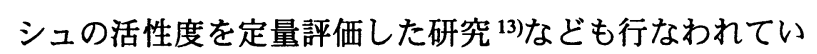
るが, 何れも強度に直接対応した指標であるとは言い難 い。例えば, 文献 ${ }^{13)}$ では, W/(C+kF)で表される係数 $\mathrm{k}$ (efficiency) によりフライアッシュの活性度を評価して いるが, $\mathrm{k}$ はフライアッシュの活性度をセメントと等価 な割合として表現するための指標であり, 結合材の活性 度を表す指標としては簡便かつ有効であるが, 強度に直 接対応した指標であるとは言い難い。それは, 後述する ように圧縮強度とセメント水比との関係式 ( $\mathrm{f}^{\prime} \mathrm{c}-\mathrm{C} / \mathrm{W}$ 関 係式）が原点を通る 1 本の直線では近似できないことと 関保している。そのため, 本研究では, 文献 ${ }^{13)}$ の手法に 改良を加え, 様々な条件下における高炬スラグ微粉末混 和コンクリートの圧縮強度に寄与する高炬スラグ微粉末 の割合を強度寄与率なる新たな指標を用いて指数化し,

実験シリーズ Iの結果を考察することとした。

ここでは, コンクリートの圧縮強度とセメント水比と の間に良好な直線関係が成り立つことを利用し, 検討を 進める。両者の関係は次式で表される。

$$
\mathrm{f}^{\prime} \mathrm{c}=\mathrm{A}+\mathrm{B} \cdot \mathrm{C} / \mathrm{W}
$$

ここで, f'c : コンクリートの圧縮強度 (MPa)

\section{A, B : 実験定数 \\ $\mathrm{C} / \mathrm{W}:$ セメント水比}

$\mathrm{f}^{\prime} \mathrm{c}-\mathrm{C} / \mathrm{W}$ 関係式は, 各温度条件, 各材齢に対して, 高 炬スラグ微粉末を混和していない水セメント比の異なる 数種類のモルタル供試体の圧縮強度試験結果より求め, 高炉スラグ微粉末を混和したモルタル供試体の圧縮強度 をこの式に代入することにより, 仮想 $\mathrm{C} / \mathrm{W}$ を求める。そ して, セメントと高炉スラグ微粉末の各々の水和物で構 成されるモルタル強度を個々に算出することにより, 高 炬スラグ微粉末混和コンクリートの圧縮強度に及ぼす高 炬スラグ微粉末の影響を評価する。図-6に $20^{\circ} \mathrm{C}$ 養生を行 つた供試体の材齢 28 日における圧縮強度（f'c）とセメ ント水比 $(\mathrm{C} / \mathrm{W})$ との関係を示す。図より, 両者は良好 な直線関係にあり, 相関係数も非常に高い。しかしなが ら，この関係式をそのまま用いると， C/W が 0.5 を下回 るような場合, 推定圧縮強度は, 負の值を示すことにな る。このようなことは実際にはあり得ない上, 強度レベ ルの非常に低い条件下（例えば， $5^{\circ} \mathrm{C}$ 養生を行った BS47 の材齢 7 日強度）では, 高炉スラグ微粉末の強度寄与率

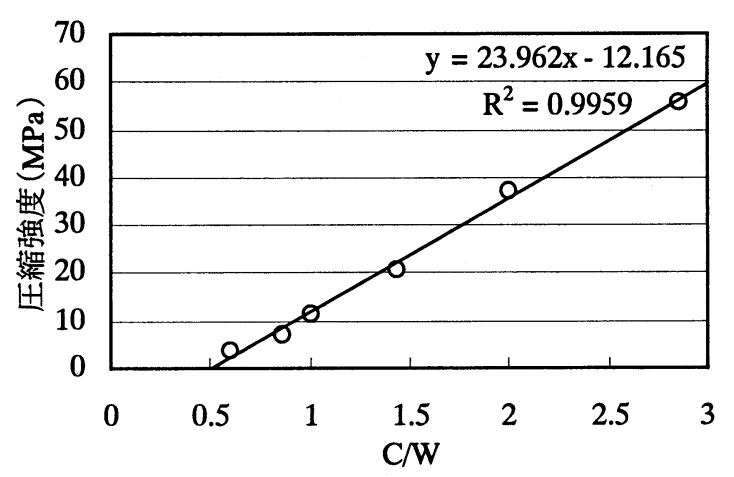

图-6 fcとC/Wとの関係 $\left(20^{\circ} \mathrm{C}, 28\right.$ 日)

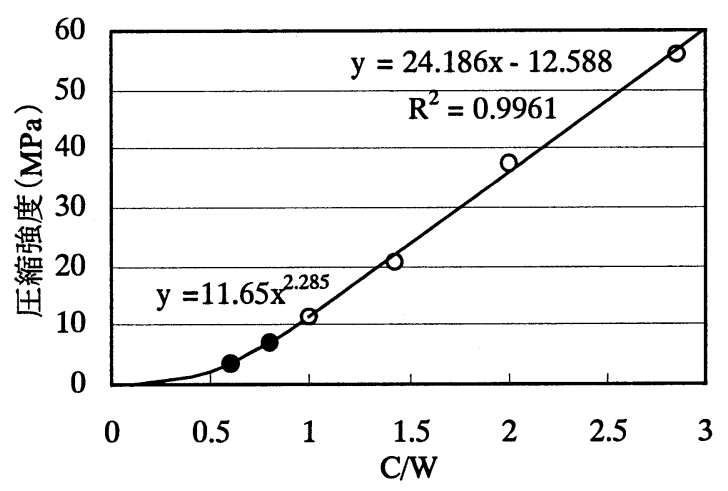

图-7 修正したfcとC/Wとの関係 $\left(20^{\circ} \mathrm{C}, 28\right.$ 日)

を正しく評価することができなくなるため, 全ての C/W に対して, 推定される圧縮強度が正の值をとるように補 正を行う。コンクリートの圧縮強度とセメント水比との 関保は, 特に $1 \leqq \mathrm{C} / \mathrm{W} \leqq 2.5$ の範囲で良好な相関を示すと 考えられるため ${ }^{14)}$, 本研究においても 1 以上の $\mathrm{C} / \mathrm{W}$ に対 して直線近似を行なうこととし, C/W が 1 以下のデータ については, 原点と $\mathrm{C} / \mathrm{w}$ が 1 の直線近似式の解を通り, $0<\mathrm{C} / \mathrm{W}<1$ の間で実測值を累乗近似することとした。結果 を図-7 に示す。この場合, C/W が 1 以上の直線近似式は 十分な相関係数を示すとともに, $\mathrm{C} / \mathrm{W}$ が 1 以下の累乗近 似式は常に正の值を示し, かつ実測值を良く近似してい る。高炬スラグ微粉末混和コンクリート中のセメントと 高炬スラグ微粉末の個々の反応における水分のやりとり は非常に複雑な現象であると考えられるが, 本研究では, 便宜上, セメントと高炉スラグ微粉末の質量比に応じて, コンクリート中の水分が各結合材に分配され，各々のぺ 一ストが個々に強度発現し, それらが融合して, 高炉ス ラグ微粉末混和コンクリートとしての強度を発揮すると 仮定した。以下, 図-7 の近似式を用いて, 普通コンクリ 一ト（BS47）を対象に, $20^{\circ} \mathrm{C}$ 養生, 材齢 28 日における, 高炉スラグ微粉末の強度寄与率の算出方法について説明 する。

1) 実験シリーズ I の結果より, $20^{\circ} \mathrm{C}$ 養生を行った普 通コンクリート（BS47）の材齡 28 日強度は 24.1MPa である。この值を図-7 中の $\mathrm{f}^{\prime} \mathrm{c}-\mathrm{C} / \mathrm{W}$ 関 係式に代入すると, 仮想セメント水比（仮想 $\mathrm{C} / \mathrm{W}=1.52)$ が得られる。すなわち, 対象となる配 

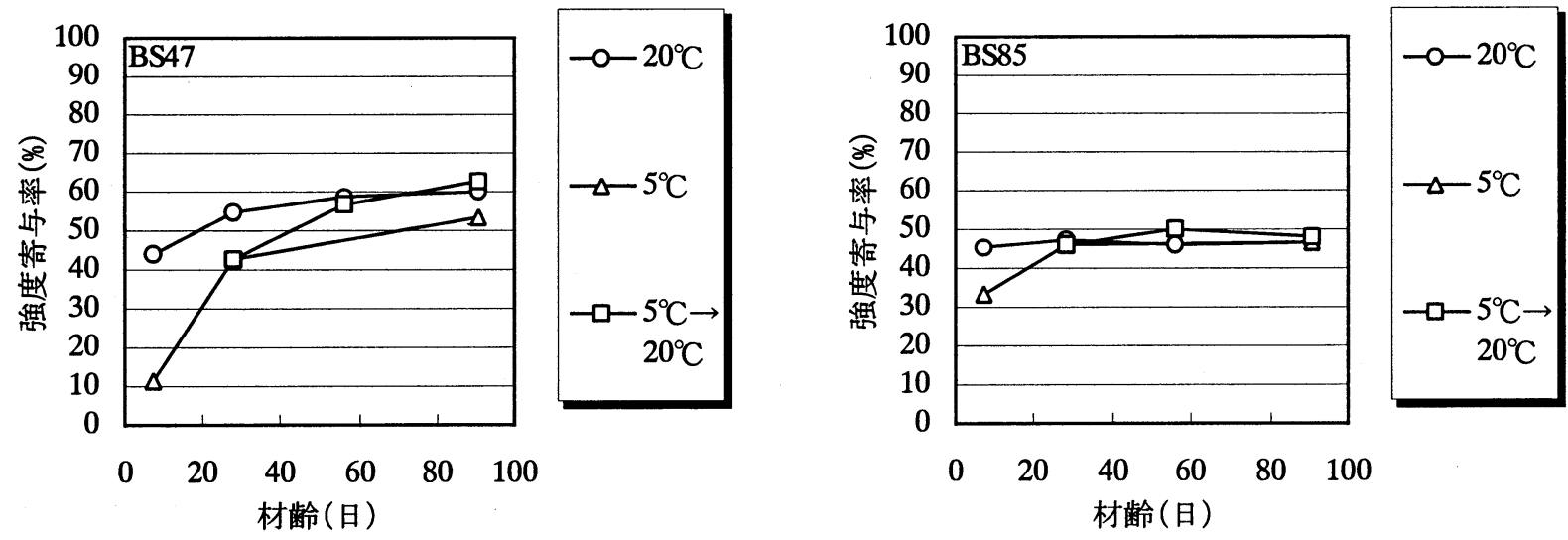

図-8＼cjkstart温度条件が高炬スラグ微粉末の強度寄与率 に及ほす影響 (高流動コンクリート)
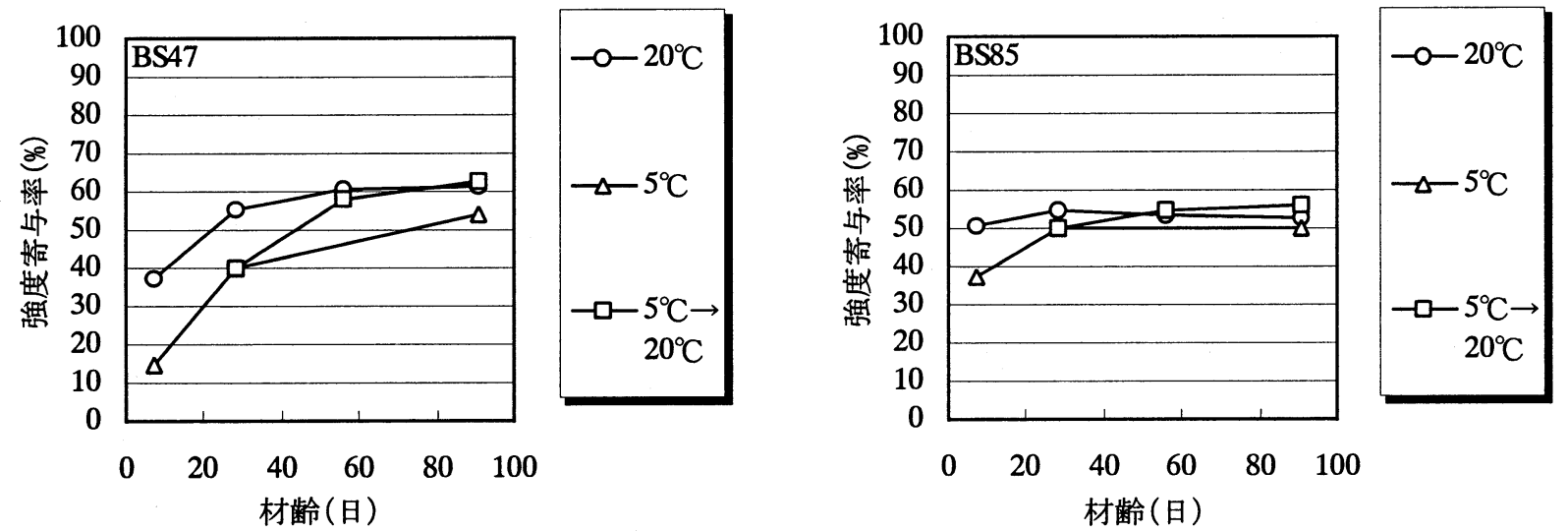

図-9 温度条件が高炉スラグ微粉末の強度寄与率 に及ぼす影響(普通コンクリート)

合は, $\mathrm{C} / \mathrm{W}=1.52$ の高炬スラグ微粉末を混和して いない配合と同じ圧縮強度を示していることに なる。

2) 対象となる配合の単位水量 $(\mathrm{W}=175 \mathrm{~kg})$ と仮想 $\mathrm{C} / \mathrm{W}$ から仮想セメント量 $\left(C^{\prime}=265 \mathrm{~kg}\right)$ を求め, C'から実 際の単位セメント量 $(\mathrm{C}=350 \times 0.3=105 \mathrm{~kg})$ を引き, 高炬スラグ微粉末のセメント当量 $\left(\mathrm{C}_{\mathrm{BS}}=\mathrm{C}^{\prime}\right.$ $\mathrm{C}=160 \mathrm{~kg}$ )を求める。ちなみに前述の係数 $\mathrm{k}$ は次式 により求まる。 $\mathrm{k}=\mathrm{C}_{\mathrm{BS}} / \mathrm{BS}=160 / 245=0.653$

すなわち, 本研究で使用した高炉スラグ微粉末 4000 の活性度は, 本実験条件下ではセメントを 1 とした場合， 0.653 に相当すると判断される。

3) 前述の仮定に基づいて, 対象となる配合のセメン トと高炉スラグ微粉末の質量比で水を分配し, セ メントと高炉スラグ微粉末が取り込む水量 $\left(\mathrm{W}_{\mathrm{c}}=\right.$ $\left.\mathrm{W} \times 0.3=52.5 \mathrm{~kg}, \mathrm{~W}_{\mathrm{BS}}=\mathrm{W} \times 0.7=122.5 \mathrm{~kg}\right)$ を求める。

4) $\mathrm{W}_{\mathrm{C}}, \mathrm{W}_{\mathrm{BS}}$ からセメントと高炉スラグ微粉末の各ペ 一ストの水比 $\left(\mathrm{C} / \mathrm{W}_{\mathrm{C}}=2.00, \mathrm{C}_{\mathrm{BS}} / \mathrm{W}_{\mathrm{BS}}=1.31\right)$ を求める。

5) $\mathrm{C} / \mathrm{W}_{\mathrm{C}}, \mathrm{C}_{\mathrm{BS}} / \mathrm{W}_{\mathrm{BS}}$ を f'-C/W 関係式に代入し, セメン トと高炉スラグ微粉末のモルタル単体強度 （ $\left.\mathrm{F}_{\mathrm{C}}=35.8 \mathrm{MPa}, \mathrm{F}_{\mathrm{BS}}=19.0 \mathrm{MPa}\right)$ を求める。

6) セメントと高炬スラグ微粉末の質量比を $F_{C}, F_{B S}$
に掛けて, セメントと高炉スラグ微粉末の寄与し ている強度 $\left(\mathrm{f}_{\mathrm{C}}=10.7 \mathrm{MPa}, \mathrm{f}_{\mathrm{BS}}=13.3 \mathrm{MPa}\right)$ を求める。 $\mathrm{f}_{\mathrm{C}}, \mathrm{f}_{\mathrm{BS}}$ の和に対する $\mathrm{f}_{\mathrm{BS}}$ の比率 $\left(\mathrm{r}_{\mathrm{BS}}=\mathrm{f}_{\mathrm{BS}} /\left(\mathrm{f}_{\mathrm{C}}+\mathrm{f}_{\mathrm{BS}}\right) \times\right.$ $100=55.4 \%)$ を算出し，これを高炉スラグ微粉末の 強度寄与率とする。

以上の評価手法に基づき高炉スラグ微粉末を混和し た高流動コンクリートと普通コンクリートを対象に, 高 炉スラグ微粉末の強度寄与率を算出した結果を図-8 及 び図-9にそれぞれ示す。図より，高炉スラグ微粉末の強 度寄与率は配合条件, 温度条件によらず材龄の経過とと もに増加している。これはセメントに比べ, 高炉スラグ 微粉末の強度に及ぼす影響が遅れて現れることを示して いる。また温度条件の違いによる強度寄与率に着目する と, BS47では $5^{\circ} \mathrm{C}$ 養生を行った場合, $20^{\circ} \mathrm{C}$ 養生と比較し て, 材齢 7 日の強度寄与率が大幅に下回っており, 材齢 が経過しても， $20^{\circ} \mathrm{C}$ 養生の強度寄与率に追いつくことは ない。一方, $\mathrm{BS} 85$ では, $5^{\circ} \mathrm{C}$ 養生を行った場合, $20^{\circ} \mathrm{C}$ 養 生と比較して, 材齢 7 日の強度寄与率は多少低い值を示 すものの, 材齢 28 日以降では温度によらず強度寄与率は ほぼ一定の值を示している。また, 温度上昇に伴い, BS47 では強度寄与率が顕著に増加するのに対して, BS85 では 多少増加する程度である。以上のことより BS47 中の高 
炉スラグ微粉末の反応性はセメントに比べ温度条件に左 右されやすいのに対して, BS85 中の高炬スラグ微粉末は 養生温度による影響を受けにくいことが確認された。

高炉スラグ微粉末がセメントと同等の反応性を有する のであれば, BS47, BS85 の高炬スラグ微粉末の強度寄 与率はそれぞれスラグ置換率と同じ $70 \%, 50 \%$ となるは ずである。BS47 の場合, 材齢が経過しても高炬スラグ微 粉末の強度寄与率は 50-60\%程度と低く, セメントと同 等の反応性を期待できないことを示している。一方, BS85 では比較的早い材齢でセメントと同等の反応性(強 度寄与率 50\%)を示す結果となった。BS85 中の高炉スラ グ微粉末がセメントと同等の反応性を示した理由は, 粉 末度の高い高炬スラグ微粉末を混和することにより, 微 粉末粒子と水分の接触機会が増加し, 材龄初期より潜在 水硬性が活性化したためと, スラグ置換率が比較的低い ため, 高炉スラグ微粉末の反応に必要な水酸化カルシウ ムがセメントから十分に供給され, 高炬スラグ微粉末の 反応が長期にわたり円滑に行われたためであると考えら れる。また, 高流動コンクリートと普通コンクリートの 材齢の経過に伴う高炬スラグ微粉末の強度寄与率の推移 を比較すると,両者の傾向に目立った違いは見られない。 すなわち, 高炬スラグ微粉末混和コンクリートの圧縮強 度に及ぼす高炉スラグ微粉末の影響は, 高流動コンクリ 一トと普通コンクリートで大きくは異ならないことが確 認された。

高炉スラグ微粉末は, それ自身の潜在水硬性によりコ ンクリートの強度に寄与する他, 無機質釷物微粉末を添 加した際に見られるような物理的な作用（微粉末効果） によりセメントの水和反応を促進させる効果も期待でき る。著者らの既往の研究 ${ }^{15)}$ により, 水セメント比 $50 \%$ の セメント単味のモルタル（05）に, セメントに対して外 割で水粉体比が 20\%になるまで石灰石微粉末を添加した 場合 (05La2), 微粉末効果により強度が著しく增進し, 材齢 7 日で $20^{\circ} \mathrm{C}$ 養生の場合, 05La2 は 05 の 1.56 倍, $0^{\circ} \mathrm{C}$ 養生の場合は 1.78 倍もの圧縮強度を示すことが確認さ れている。本研究で考案した手法では, この効果も高炉 スラグ微粉末の反応性に含めて評価しているため, 今後 は，コンクリートの強度に及ぼす高炬スラグ微粉末の化 学的作用（潜在水硬性）之物理的作用（微粉末効果）に よる影響を分けて評価する必要があると思われる。

\section{4. 結論}

本研究により得られた主な結果を以下に示す。

1）高炉スラグ微粉末混和コンクリートを寒冷地にお いて使用する場合, 初期の強度発現性が遅延し, その傾向は高炬スラグ微粉末の粉末度が低く置換 率が高い配合でより顕著に現れるが，冬から春へ の温度上昇に伴い, 封かん状態が保たれていれば, 顕著に強度回復する。初期の強度発現を改善させ
る目的で, 強度発現性の低い配合に対して給熱盖 生を行なうことは有効であるが, 低温下において も良好な強度発現性を示す配合に対しては, 長期 の強度発現性に悪影響を及ぼすため, むしろこれ を避けるべきである。

2）常温を基準とした場合の低温下における高炉スラ グ微粉末混和コンクリートの強度発現性及び温度 上昇に伴う強度回復傾向は, 普通コンクリートに 比べ高流動コンクリートを対象とした配合の方が 優れており, 給熱養生による強度発現改善効果は, 高流動コンクリートに比べ普通コンクリートを対 象とした配合でより顕著に現れる。

3）コンクリートの圧縮強度とセメント水比との関係 式を利用し, 様々な条件下における高炬スラグ微 粉末混和コンクリートの圧縮強度に寄与する高炉 スラグ微粉末の割合を指数化する手法を考案した。 この手法を用いて本実験データを分析した結果, 粉末度の低い高炉スラグ微粉末を高い置換率で混 和した場合, 低温下において, セメントに比べ高 炉スラグ微粉末の初期の反応性が著しく低下する とともに, 材齢が経過してもセメントと同等の反 応性が期待できないのに対し, 粉末度の高い高炉 スラグ微粉末を比較的低い置換率で混和した場合, 低温下においてもセメントと同等かそれ以上の高 炉スラグ微粉末の反応性が期待できることを明ら かにした。

1) 土木学会コンクリート委員会 : 高炉スラク微粉末を用いたコン クリートの施工指針, 土木学会, 1996.6

2）融雪夙によるコンクリート構造物の劣化研究委員会 : 報告集 · 論文集, 日本コンクリートエ学協会, 1999.11

3) 鈴木一利, 岩城一郎, 三浦尚 : 寒冷地における高炉スラグ微粉 末混和コンクリートの強度発現, コンクリート工学年次論文報告 集, Vol.19, No.1, pp.247-252, 1997.6

4) 岩城一郎, 鈴木一利, 三浦尚 : 低温養生を行った高炉スラグ混 和コンクリートの強度回復特性, コンクリート工学年次論文報告 集, Vol.20, No.2, pp.205-210, 1998.6

5) Miura, T. and Iwaki, I. : Strength development of concrete incorporating high levels of ground granulated blast-furnace slag at low temperatures, ACI Materials Journal, Vol.97, No.1, pp.66-70, 2000.2

6) 岩城一郎, 三浦尚 : 寒冷地における高炬スラグ微粉末混和高流 動コンクリートの強度発現性に関する基礎的研究, 土木学会論文 集, No.655, 2000.8

7) 岩城一郎, 澤井洋介, 三浦尚 : 高炬スラグ混和コンクリートの 強度発現に及ぼす配合及び温度の影䇺, コンクリートエ学年次論 文報告集, Vol.22, No.2, pp.127-132, 2000.6

8）土木学会コンクリート委員会 : 高流動コンクリート施工指針, 土木学会, 1998.7 
9) 岡村甫, 前川宏一, 小澤一雅 : ハイパフォーマンスコンクリー 卜，技報堂出版， 1993

10) 土木学会コンクリート委員会 : コンクリート標準示方書 [施工 編], 土木学会, 1996.6

11）近藤連一, 大沢栄也 : 高炉水碀スラグの定量およびセメント中 のスラグの水和反応速度に関する研究, 䆛業協会誌, Vol.77, No.2, pp.39-46, 1969.2

12)近松竜一, 山本泰彦: 高炬スラグ微粉末の活性度の新しい評価 方法, 土木学会論文集, No.414, 土木学会論文集, pp.119-128, 1990.2
13) 例えば, Babu, K.G. and Rao, G.S.N. : Efficiency of Fly Ash in Concrete with Age, Cement and Concrete Research, Vol.26, No.3, pp.465-474, 1996.

14) 岡田清, 六車熙 : コンクリート工学ハンドブック, 朝倉書店, 1981.11

15）岩城一郎, 三浦尚：低温堽境下における石灰石微粉末を添加し たコンクリートの強度発現性に関する基礎的研究, 土木学会論文

集, No.655, 2000.8

（原稿受理年月日： 2000 年 5 月 11 日）

Study on Strength Development of Concrete Incorporating

Ground Granulated Blast-Furnace Slag Used in Cold Regions

By Ichiro IWAKI, Yosuke SAWAI, Hirokazu KAJITANI and Takashi MIURA

Concrete Research and Technology, Vol.12, No.2, May 2001

Synopsis: Using mortar specimens associated with self-compacting concrete and normal concrete incorporating ground granulated blast-furnace slag (ggbs), the strength development for various curing temperatures supposing cold regions was researched. The experimental results revealed that the strength development is varied by the incorporation of ggbs, its specific surface area and replacement level, and the difference between self-compacting concrete and normal concrete. Thus suggesting the method for evaluating the effect of ggbs to the strength development of ggbs-concrete quantitatively, the influences of mixture proportion and curing temperature to the strength development of such concrete were investigated.

Keywords: Ground Granulated Blast-Furnace Slag, Strength Development, Curing, Self-Compacting Concrete, Rate of Strength Contribution 